\title{
Anemia among Adult Diabetic Patients Attending a General Hospital in Eastern Ethiopia: a Cross-sectional Study
}

This article was published in the following Dove Press journal: Diabetes, Metabolic Syndrome and Obesity: Targets and Therapy

\author{
Teshome Tujuba' \\ Behailu Hawulte Ayele (D) $^{2}$ \\ Sagni Girma Fage $\mathbb{D}^{3}$ \\ Fitsum Weldegebreal $\mathbb{D}^{4}$ \\ 'Department of Medical Laboratory, \\ Gelemso General Hospital, Gelemso, \\ Ethiopia; ${ }^{2}$ School of Public Health, \\ College of Health and Medical Sciences, \\ Haramaya University, Harar, Ethiopia; \\ ${ }^{3}$ School of Nursing and Midwifery, \\ College of Health and Medical Sciences, \\ Haramaya University, Harar, Ethiopia; \\ ${ }^{4}$ College of Health and Medical Sciences, \\ Haramaya University, Harar, Ethiopia
}

Correspondence: Sagni Girma Fage College of Health and Medical Sciences, Haramaya University, P.O.Box 235, Harar, Ethiopia

Email giruu06@gmail.com
Background: Although anemia is a common condition among patients with diabetes mellitus, there is little evidence on anemia among this segment of population in Ethiopia at large and in the study setting in particular. Thus, this study aimed at assessing the magnitude of anemia and its associated factors among adult diabetic patients attending a general hospital in Eastern Ethiopia.

Methods: A health facility-based cross-sectional study was conducted among 325 randomly selected adult diabetes mellitus patients attending a follow-up clinic at Gelemso General Hospital, Eastern Ethiopia. Data were collected through an interview using a pre-tested and structured questionnaire followed by physical and laboratory measurements. Data were then entered into EpiData Version.3.1 and analyzed by using STATA version 16.0. Binary logistic regression models were fitted to identify factors associated with anemia. All statistical tests were declared significant at $p$-value $<0.05$.

Results: The magnitude of anemia among adult diabetic patients was $30.2 \%$ (95\% confidence interval (CI): $25.4 \%-35.4 \%)$. Anemia was higher in males (36\%) than females $(20.5 \%)$. Male gender (Adjusted Odds Ratio $(\mathrm{AOR})=2.1,95 \% \mathrm{CI}: 1.2,3.8)$, DM duration of $\geq 5$ years $(\mathrm{AOR}=$ 1.9, 95\% CI: 1.0, 3.7), presence of comorbidity ( $\mathrm{AOR}=1.9,95 \% \mathrm{CI}: 1.0,3.7)$, and having diabetic complications ( $\mathrm{AOR}=2.3,95 \% \mathrm{CI}: 1.3,4.2$ ) were significantly associated with anemia. Conclusion: Anemia was a moderate public health problem among adult DM patients in the study setting. Being male in gender, duration of DM, presence of DM complications, and DM co-morbidities were factors associated with anemia. Therefore, routine screening and appropriate management of anemia targeting males, DM patients with longer duration of $\mathrm{DM}$, and those with complications and co-morbidities should be devised to improve patients' quality of life. Early diagnosis and regular monitoring of DM could also help to minimize further complications.

Keywords: anemia, diabetes mellitus, general hospital, Eastern Ethiopia

\section{Background}

Anemia is a reduction in the number of circulating red blood cells (RBC) and/or consequently their oxygen-carrying capacity in an insufficient way to meet the body's physiologic need. ${ }^{1,2}$ It affects both developing and developed countries, with major consequences on human health, social and economic development. ${ }^{3}$ Globally, about 1.62 billion people were anemic and this corresponds to $24.8 \%$ of the global population. ${ }^{4}$

Diabetes mellitus (DM) is a metabolic disorder and it is broadly classified as type I juvenile or insulin-dependent diabetes and type II_non insulin-dependent 
diabetes. ${ }^{5}$ In diabetic patients, anemia is mainly attributed to inflammation, drugs, nutritional deficiency, kidney diseases, concomitant autoimmune disorders, ${ }^{6,7}$ the relative decrease in erythropoietin production, absolute or functional iron deficiency, and shortened red cell survival. ${ }^{8,9}$ And therefore anemia is common in patients with diabetes. $^{10,11}$ Among adults, the prevalence of anemia was $24 \%$ in women of reproductive age (15-49 years) and $15 \%$ for men aged $15-49$ years. $^{12}$

Among patients with DM, particularly those with overt nephropathy or renal impairment, the prevalence of anemia is about two to three folds higher than in individuals without DM. ${ }^{13,14}$ Anemia is associated with an increased risk of vascular complications of diabetes such as nephropathy, retinopathy, neuropathy, impaired wound healing, and macro-vascular disease, ${ }^{15,16}$ which have negative impacts on the patients' quality of life. ${ }^{17-19}$ Despite these facts, studies reported that anemia is unrecognized in up to $25 \%$ of diabetic patients. ${ }^{20,21}$

Early recognition and treatment of anemia in patients with DM could help to decrease morbidity and mortality and improve their quality of life. ${ }^{22}$ But, only a few studies have assessed anemia among diabetic patients in Ethiopia in general and no study was conducted so far in the study area in particular. Hence, this study aimed to estimate the magnitude of anemia and identify factors associated with it among diabetic patients at Gelemso General Hospital, Eastern Ethiopia.

\section{Methods and Materials}

\section{Study Setting}

This study was conducted at Gelemso General Hospital (GGH) which is located in Gelemso town in Habro district, West Hararghe zone of Oromia Regional State in Eastern Ethiopia. The hospital is found at about $390 \mathrm{~km}$ to the east of Addis Ababa, the capital of Ethiopia. ${ }^{23}$ According to Habro woreda health office reports, GGH serves as a referral center for an estimated 1.4 million population in the surrounding catchment area. It offers health services for more than 90,000 patients per year in its different units and clinics. Diabetic clinic is among the specialized units providing services for about 660 diabetic patients. Habro district is located at an altitude of 1800-2000 meters above sea level.

\section{Study Design and Population}

A hospital-based cross-sectional study was conducted from June 9th to August 10th, 2020. Eligible participants were adult ( $\geq 18$ years) diabetic patients attending follow up clinic at GGH. Adult diabetic patients who received a blood transfusion within the last 3 months, those who were pregnant or had recent delivery or have psychiatric illness, those with surgical procedures or bleeding due to any reason, and who were on treatment for intestinal parasites were excluded from the study.

\section{Sample Size and Sampling Techniques}

The sample size was determined by using a single population proportion formula with the assumptions of; $95 \%$ confidence interval, 5\% margin of error, and prevalence of anemia $(p=26.7 \%$ ) from a previous study among people with diabetes in Dessie Referral Hospital, Northeast of Ethiopia. ${ }^{24}$ After adding $10 \%$ for non-response, the final sample size was 331 .

Six hundred sixty diabetic patients were attending a diabetic clinic in GGH for their active follow-up. The total number of diabetic patients (660) was divided for the final sample size (331) yielding a sampling interval of two. By using the register book of diabetic patients attending diabetic follow-up services at the hospital as a sampling frame, we applied a systematic random sampling technique to enroll every other patient in to the study. Each study participant was given a unique identification number to avoid repetition in case the same patient shows up again for another follow-up visit during the study period.

\section{Data Collection Tools and Procedures Questionnaires}

Data on socio-demographic variables, alcohol consumption, smoking, and dietary characteristics were collected by using a structured questionnaire adapted from the WHO stepwise approach to chronic disease risk factor surveillance manual. ${ }^{25}$ The questionnaires for Tea and Coffee consumption, Shisha use, Khat chewing, contraceptive use, and menstruation history were developed by reviewing different literatures. ${ }^{26-30}$ The questionnaires were prepared in English and translated to the local language (Afaan Oromoo) and translated back to English by different language experts to check for consistency. Clinical data such as duration of diabetes, type of DM, complications of DM, and fasting blood glucose levels were obtained from patients' medical records. Data were collected by two professional nurses and one laboratory technologist and supervised by one Master of Public Health graduate. 


\section{Physical Measurements}

Blood pressure (BP) was measured using a digital BP apparatus (Heuer) which was regularly validated. Before measuring BP, it was checked that the subjects did not consume any hot beverages, such as tea or coffee or smoked tobacco, chewed Khat, or undertaken vigorous physical activity within the last 30 minutes. Three separate measurements were obtained on the left arm after the subject was rested for at least five minutes and the average BP reading was recorded. The second and third measurements were taken five and ten minutes after the first and second measurements, respectively. Hypertension was defined as elevated $\mathrm{BP}$ (SBP $\geq 140$ or DBP $\geq 90 \mathrm{mmHg}$ ) or well-known previously diagnosed hypertensive patient taking the antihypertensive medications. ${ }^{31,32}$

To determine nutritional status by body mass index (BMI), we measured the patients' height and weight. Height was measured using a stadiometer while each participant is standing erect against the wall with heels together touching the wall, without shoes, head held in an upright position, and recorded to the nearest $0.1 \mathrm{~cm}$. Weight was measured using a digital weight scale labeled 0 to $130 \mathrm{~kg}$. The scale was calibrated to zero level before each measurement. Weight was measured while participants were with light clothes, without footwear, and recorded to the nearest $0.1 \mathrm{~kg} .{ }^{33,34}$ Body mass index (BMI) was calculated as weight in kilograms divided by the squared height in meters. Nutritional status was then defined as; underweight if $\mathrm{BMI}<18.5$, normal if $\mathrm{BMI}=18.5-24.9$, over-weight if $\mathrm{BMI}=$ 25-29.9, and obese if BMI $\geq 30 .^{35,36}$

Waist circumference was measured using a non-elastic measuring tape at the approximate midpoint between the lower margin of the last palpable rib and the top of the iliac crest and recorded to the nearest $0.1 \mathrm{~cm}$. Central obesity was defined by waist circumference thresholds $\geq$ $94 \mathrm{~cm}$ for men and $\geq 80 \mathrm{~cm}$ for women. ${ }^{30,36}$ Relative technical error of measurement (\%TEM) was calculated during training among 10 adult diabetic patients to minimize random anthropometric measurement errors. The accepted relative technical measurement error for intraobserver and inter-observers were less than $1.5 \%$ and less than $2 \%$, respectively.

\section{Laboratory Measurements}

About two milliliter $(2 \mathrm{~mL})$ blood samples were collected from all participants into a test tube containing tri- potassium ethylene diamine tetraacetate (EDTA K3) anticoagulants by a laboratory technologist for hemoglobin determination. The collected whole blood was mixed properly and analyzed using the Sysmex XN-550 hematology analyzer. Hemoglobin measurements were adjusted for altitude by deducting $0.8 \mathrm{~g} / \mathrm{dl}$ for all participants, and for smoking status by deducting $0.03 \mathrm{~g} / \mathrm{dl}$. Anemia was then defined as hemoglobin level $<12 \mathrm{~g} / \mathrm{dl}$ for women and $<13 \mathrm{~g} /$ $\mathrm{dl}$ for men. The severity of anemia was categorized as; hemoglobin levels of $11-12.9 \mathrm{~g} / \mathrm{dl}$ and $11-11.9 \mathrm{~g} / \mathrm{dl}$ were mild anemia for males and females, respectively, while hemoglobin levels of $8-10.9 \mathrm{~g} / \mathrm{dl}$ and $<8 \mathrm{mg} / \mathrm{dl}$ were moderate and severe anemia, respectively, for both sex. ${ }^{1}$

Five milliliter $(5 \mathrm{~mL})$ venous blood was collected into a test tube without anti-coagulant for Creatinine and Urea determination. The whole blood without anticoagulant was allowed to clot for 20-30 minutes and centrifuged at $3000 \mathrm{rpm}$ for five minutes to separate serum. Then, serum Creatinine and Urea were determined by kinetic alkaline picrate and enzymatic method by using Mindray BS-200E (Shenzhen Mindray Bio-Medical Electronics Co. Ltd, China) clinical chemistry analyzer, respectively. ${ }^{37} \mathrm{The}$ Creatinine Clearance was used to estimate Glomerular Filtration Rate (GFR) by using Chronic Kidney Disease (CKD) CKD-EPI Cockroft-Gault formula expressed per $1.73 \mathrm{~m}^{2}$.

Fasting blood glucose level was measured in a (at least $8 \mathrm{hrs}$ ) by finger prick using a blood glucometer that was calibrated for plasma glucose values. ${ }^{38}$ It was coded as uncontrolled glycemic control if fasting blood glucose level was $<80$ or $>130 \mathrm{mg} / \mathrm{dl}$ and controlled when fasting blood glucose value was between 80 and $130 \mathrm{mg} / \mathrm{dl}^{39}$

Study participants were provided with a clean wooden applicator stick and clean, dry, and leak-proof plastic cup labeled with the subjects' serial number for stool parasite examination. They were instructed to bring two grams (about thumb size) of fresh stool sample. The examination of the specimen was done within 30 minutes of sample collection using a direct wet mount technique to detect Helminthes (eggs and/or larvae). The remaining samples were preserved in a tube that contains $10 \mathrm{~mL}$ of $10 \%$ formalin to increase the parasite detection rate and examined using Olympus Microscopic after processing with the formalin-ether sedimentation concentration technique.

The capillary blood sample was collected by finger prick using a sterile lancet for malaria detection. Thick and thin blood films were prepared on the same greasefree, clean glass, and air-dried. The slides were stained 
with $10 \%$ Giemsa for about 10 minutes and screened for Plasmodium species. Slides were considered negative when 100 high power fields were examined under the oil immersion objective. ${ }^{40}$

\section{Data Quality Assurance}

Data collectors and supervisors were trained for two days on data collection tools and methods. The questionnaires were pre-tested before the actual data collection among 30 diabetic patients at Chiro General Hospital and necessary modifications were considered accordingly. Physical measurements were standardized by the relative technical error of measurement ( $\%$ TEM). Furthermore, standard operating procedures were followed during all laboratory sample collection, storage, analysis process, and recording.

\section{Ethical Considerations}

Ethical clearance was obtained from the Institutional Health Research Ethics Review Committee (IHRERC) of the College of Health and Medical Sciences, Haramaya University (Ref. No. IHRERC 115/2020). An official letter of support was written from the college to the GGH and permission was obtained from the head of the hospital. Informed, voluntary, written and signed consent was obtained from each study participant before data collection. Participants were informed that all data collected from them will be kept confidential by using codes and no personal identifiers will be used and were meant only for the purpose of research. This study was conducted in accordance with the Declaration of Helsinki.

\section{Data Processing and Analysis}

The collected data were checked for completeness, coded, and entered into EpiData version 3.1, and exported to STATA version 16.0 for data management and analysis. Data were described using percent, proportion, mean, and standard deviation. Anemia status was determined based on the new WHO classification after the hemoglobin level was adjusted for participants' smoking status, and the altitude of the district. Bivariate logistic regression model was fitted to identify variables for the final multivariable logistic regression analysis. Variables with $p$-value $\leq 0.25$ in bivariate logistic regression were considered as candidates for multivariable logistic regression. Multivariable logistic regression model was built to identify factors independently associated with anemia. The strength of association was measured using odds ratio along with the
$95 \%$ confidence interval. The level of statistical significance was declared at $p$-value $<0.05$.

\section{Results}

\section{Socio-demographic Characteristics of Participants}

In this study, a total of 325 adult DM patients participated yielding a response rate of $98.2 \%$. Majority of the participants; 203 (62.5\%), 247 (76\%), 204 (62.8\%), and 279 $(85.5 \%)$ were males, married, from rural areas, and Oromo in ethnicity, respectively. The median age of participants was 40 years with Interquartile Range (IQR) of 20 years. About $62 \%$ of the participants had never attended formal education and $52.6 \%$ were farmers in occupation (Table 1).

Table I Socio-demographic Characteristics of Adult DM Patients Attending a General Hospital in Eastern Ethiopia, 2020 $(\mathrm{N}=325)$

\begin{tabular}{|c|c|c|c|}
\hline Variables & Category & $\begin{array}{l}\text { Frequency } \\
\text { (n) }\end{array}$ & $\begin{array}{l}\text { Percent } \\
\text { (\%) }\end{array}$ \\
\hline Gender & $\begin{array}{l}\text { Male } \\
\text { Female }\end{array}$ & $\begin{array}{l}203 \\
122\end{array}$ & $\begin{array}{l}62.5 \\
37.5\end{array}$ \\
\hline Residence & $\begin{array}{l}\text { Urban } \\
\text { Rural }\end{array}$ & $\begin{array}{l}121 \\
204\end{array}$ & $\begin{array}{l}37.2 \\
62.8\end{array}$ \\
\hline Age in years & $\begin{array}{l}18-25 \\
26-40 \\
4 I-55 \\
\geq 56\end{array}$ & $\begin{array}{l}55 \\
129 \\
78 \\
63\end{array}$ & $\begin{array}{l}16.9 \\
39.7 \\
24.0 \\
19.4\end{array}$ \\
\hline $\begin{array}{l}\text { Educational } \\
\text { status }\end{array}$ & $\begin{array}{l}\text { No formal } \\
\text { education } \\
\text { Primary school } \\
\text { Secondary school } \\
\text { College and above }\end{array}$ & $\begin{array}{l}201 \\
79 \\
24 \\
21\end{array}$ & $\begin{array}{l}61.8 \\
24.3 \\
7.4 \\
6.5\end{array}$ \\
\hline Religion & $\begin{array}{l}\text { Muslim } \\
\text { Christian }\end{array}$ & $\begin{array}{l}253 \\
72\end{array}$ & $\begin{array}{l}77.8 \\
22.2\end{array}$ \\
\hline Marital status & $\begin{array}{l}\text { Single } \\
\text { Married } \\
\text { Divorced/widowed }\end{array}$ & $\begin{array}{l}51 \\
247 \\
27\end{array}$ & $\begin{array}{l}15.7 \\
76.0 \\
8.3\end{array}$ \\
\hline $\begin{array}{l}\text { Occupational } \\
\text { status }\end{array}$ & $\begin{array}{l}\text { Government } \\
\text { employee } \\
\text { Self-employed } \\
\text { Farmer } \\
\text { Student } \\
\text { Retired } \\
\text { Unemployed }\end{array}$ & $\begin{array}{l}21 \\
93 \\
171 \\
17 \\
5 \\
18\end{array}$ & $\begin{array}{l}6.5 \\
28.6 \\
52.6 \\
5.2 \\
1.5 \\
5.5\end{array}$ \\
\hline
\end{tabular}




\section{Behavioral and Nutritional}

\section{Characteristics}

Of the study participants, $74(22.8 \%)$ reported that they have smoked cigarettes at least once in their lifetime and only $13(4 \%)$ were current smokers. Besides, 12 (3.7\%) of the participants were current alcohol users while $64.3 \%$ of the study participants were khat chewers. More than one third $(68.3 \%)$ of the study participants reported to have a habit of taking coffee always after a meal. Three hundred thirteen (96.3\%) and $310(95.4 \%)$ participants ate fruits and vegetables less than five times per week, respectively. Regarding their nutritional status, $92(28.3 \%)$ and $164(50.5 \%)$ of the study participants had overweight and central obesity, respectively (Table 2).

Table 2 Behavioral and Nutritional Characteristics of Adult DM Patients Attending a General Hospital in Eastern Ethiopia, 2020 $(\mathrm{N}=325)$

\begin{tabular}{|c|c|c|c|}
\hline Variables & Category & $\begin{array}{l}\text { Frequency } \\
\text { (n) }\end{array}$ & $\begin{array}{l}\text { Percent } \\
\text { (\%) }\end{array}$ \\
\hline Current Khat chewer & $\begin{array}{l}\text { Yes } \\
\text { No }\end{array}$ & $\begin{array}{l}209 \\
116\end{array}$ & $\begin{array}{l}64.3 \\
35.7\end{array}$ \\
\hline Ever smoker & $\begin{array}{l}\text { Yes } \\
\text { No }\end{array}$ & $\begin{array}{l}74 \\
251\end{array}$ & $\begin{array}{l}22.8 \\
77.2\end{array}$ \\
\hline $\begin{array}{l}\text { Current alcohol user } \\
\text { (who drank alcohol in the } \\
\text { past } 30 \text { days) }\end{array}$ & $\begin{array}{l}\text { Yes } \\
\text { No }\end{array}$ & $\begin{array}{l}12 \\
313\end{array}$ & $\begin{array}{l}3.7 \\
96.3\end{array}$ \\
\hline Coffee use after a meal & $\begin{array}{l}\text { Yes } \\
\text { No }\end{array}$ & $\begin{array}{l}222 \\
103\end{array}$ & $\begin{array}{l}68.3 \\
31.7\end{array}$ \\
\hline Tea use after a meal & $\begin{array}{l}\text { Yes } \\
\text { No }\end{array}$ & $\begin{array}{l}12 \\
313\end{array}$ & $\begin{array}{l}3.7 \\
96.3\end{array}$ \\
\hline $\begin{array}{l}\text { Fruits consumption per } \\
\text { week }\end{array}$ & $\begin{array}{l}<5 \text { times } \\
\geq 5 \text { times }\end{array}$ & $\begin{array}{l}313 \\
12\end{array}$ & $\begin{array}{l}96.3 \\
3.7\end{array}$ \\
\hline $\begin{array}{l}\text { Vegetables consumption } \\
\text { per week }\end{array}$ & $\begin{array}{l}<5 \text { times } \\
\geq 5 \text { times }\end{array}$ & $\begin{array}{l}310 \\
15\end{array}$ & $\begin{array}{l}95.4 \\
4.6\end{array}$ \\
\hline $\begin{array}{l}\text { Meat consumption per } \\
\text { week }\end{array}$ & $\begin{array}{l}<5 \text { times } \\
\geq 5 \text { times }\end{array}$ & $\begin{array}{l}312 \\
13\end{array}$ & $\begin{array}{l}96.0 \\
4.0\end{array}$ \\
\hline $\begin{array}{l}\text { Egg consumption per } \\
\text { week }\end{array}$ & $\begin{array}{l}<5 \text { times } \\
\geq 5 \text { times }\end{array}$ & $\begin{array}{l}311 \\
14\end{array}$ & $\begin{array}{l}95.7 \\
4.4\end{array}$ \\
\hline $\begin{array}{l}\text { Nutritional status (BMI } \\
\text { in } \mathrm{kg} / \mathrm{m}^{2} \text { ) }\end{array}$ & $\begin{array}{l}<18.5 \\
18.5-24.9 \\
\geq 25\end{array}$ & $\begin{array}{l}33 \\
200 \\
92\end{array}$ & $\begin{array}{l}10.2 \\
61.5 \\
28.3\end{array}$ \\
\hline Central obesity & $\begin{array}{l}\text { Yes } \\
\text { No }\end{array}$ & $\begin{array}{l}164 \\
161\end{array}$ & $\begin{array}{l}50.5 \\
49.5\end{array}$ \\
\hline
\end{tabular}

\section{Clinical Characteristics of Study}

\section{Participants}

More than half, 170 (52.3\%) of participants were type II DM patients and the mean duration of DM were 4.5 (SD \pm 4.0 ) years. Almost $50 \%$ of the DM patients were taking oral hypoglycemic agents (Glibenclamide and/or Metformin) and nearly three fourth of the study participants have uncontrolled blood glucose (Table 3). Regarding co-morbidity, $2 \%$ of the participants have comorbidity. Eighty (24.6\%) and $173(53.2 \%)$ of DM patients with no hypertension were anemic and nonanemic, respectively. On the other hand, of those DM patients with diagnosis of hypertension, 189 (5.5\%) and $54(16.6 \%)$ were found to be anemic and non-anemic, respectively.

Table 3 Clinical Characteristics of Adult DM Patients Attending a General Hospital in Eastern Ethiopia, 2020 (N= 325)

\begin{tabular}{|c|c|c|c|}
\hline Variables & Category & $\begin{array}{l}\text { Frequency } \\
\text { (n) }\end{array}$ & $\begin{array}{l}\text { Percent } \\
\text { (\%) }\end{array}$ \\
\hline Type of DM & $\begin{array}{l}\text { Type I } \\
\text { Type II }\end{array}$ & $\begin{array}{l}155 \\
170\end{array}$ & $\begin{array}{l}47.7 \\
52.3\end{array}$ \\
\hline Duration of DM & $\begin{array}{l}\leq \mathrm{I} \text { year } \\
\mathrm{I}-5 \text { years } \\
\geq 5 \text { years }\end{array}$ & $\begin{array}{l}91 \\
111 \\
123\end{array}$ & $\begin{array}{l}28.0 \\
34.2 \\
37.8\end{array}$ \\
\hline $\begin{array}{l}\text { Presence of co- } \\
\text { morbidity }\end{array}$ & $\begin{array}{l}\text { Yes } \\
\text { No }\end{array}$ & $\begin{array}{l}91 \\
234\end{array}$ & $\begin{array}{l}28.0 \\
72.0\end{array}$ \\
\hline $\begin{array}{l}\text { Medications used for } \\
\text { DM }\end{array}$ & $\begin{array}{l}\text { Oral } \\
\text { hypoglycemic } \\
\text { agents } \\
\text { Insulin } \\
\text { Both }\end{array}$ & $\begin{array}{l}146 \\
172 \\
7\end{array}$ & $\begin{array}{l}44.9 \\
\\
52.9 \\
2.2\end{array}$ \\
\hline $\begin{array}{l}\text { Medications taken for } \\
\text { co-morbidities }\end{array}$ & $\begin{array}{l}\text { Yes } \\
\text { No }\end{array}$ & $\begin{array}{l}71 \\
254\end{array}$ & $\begin{array}{l}21.8 \\
78.2\end{array}$ \\
\hline DM complications ${ }^{\mathrm{a}}$ & $\begin{array}{l}\text { Yes } \\
\text { No }\end{array}$ & $\begin{array}{l}76 \\
249\end{array}$ & $\begin{array}{l}23.4 \\
76.6\end{array}$ \\
\hline Blood glucose level & $\begin{array}{l}\text { Controlled } \\
\text { Uncontrolled }\end{array}$ & $\begin{array}{l}82 \\
243\end{array}$ & $\begin{array}{l}25.2 \\
74.8\end{array}$ \\
\hline Hypertension & $\begin{array}{l}\text { Yes } \\
\text { No }\end{array}$ & $\begin{array}{l}72 \\
253\end{array}$ & $\begin{array}{l}22.2 \\
77.8\end{array}$ \\
\hline Hypertension $(n=72)$ & $\begin{array}{l}\text { Controlled } \\
\text { Uncontrolled }\end{array}$ & $\begin{array}{l}40 \\
32\end{array}$ & $\begin{array}{l}55.6 \\
44.4\end{array}$ \\
\hline Stool examination & $\begin{array}{l}\text { Positive } \\
\text { Negative }\end{array}$ & $\begin{array}{l}4 \\
321\end{array}$ & $\begin{array}{l}1.2 \\
98.8\end{array}$ \\
\hline
\end{tabular}

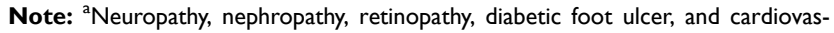
cular diseases. 


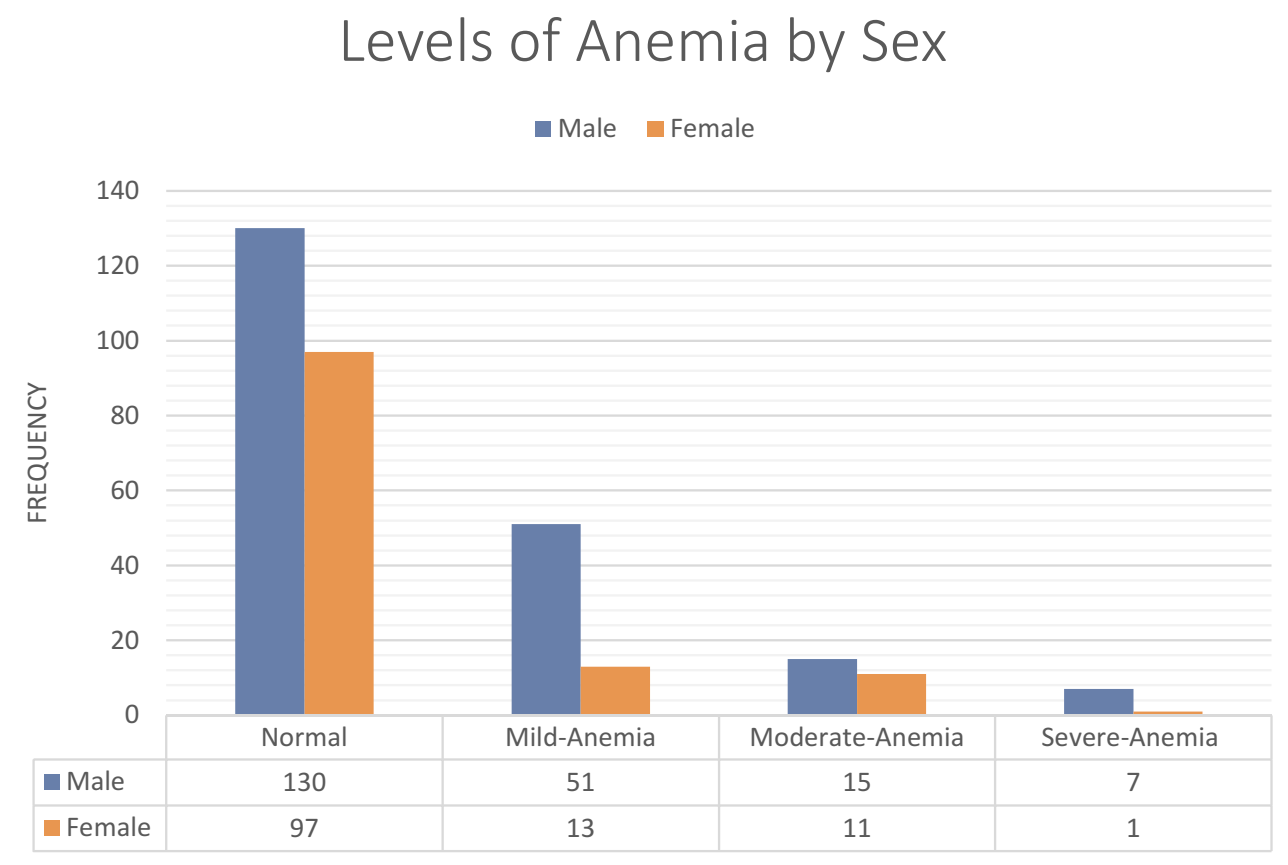

Figure I Levels of Anemia by Gender among Adult DM Patients Attending a General Hospital in Eastern Ethiopia, 2020(N=325).

\section{Anemia and Its Severity}

The magnitude of anemia among DM patients was $30.2 \%$ (95\% CI: 25.4-35.4\%) and the mean hemoglobin level was $13.2 \pm 2.3 \mathrm{~g} / \mathrm{dl}(13.4 \pm 2.3 \mathrm{~g} / \mathrm{dl}$ for males and $12.9 \pm 1.7 \mathrm{~g} / \mathrm{dl}$ for females). Concerning the severity of anemia among anemic DM patients, $64(65.3 \%)$ were mildly anemic, 26 (26.5\%) were moderately anemic, and $8(8.2 \%)$ were severely anemic. Anemia was significantly higher in males $(36.0 \%)$ than in females $(20.5 \%)(p=0.003)$ (Figure 1). We found significant and positive correlation between severity of anemia and duration of DM ( $r=$ $0.1556, p=0.0049$ ). This means that there is a tendency of increasing the severity of anemia with an increase in the duration of DM.

Sixty-four percent of males and $79.5 \%$ of female adult DM patients were non-anemic while $28.7 \%$ and $71.3 \%$ of current Khat chewers were anemic and nonanemic, respectively. Sixty-seven percent of adult DM patients who use coffee after meal were non-anemic whereas, $32.9 \%$ of them were found to be anemic. Regarding the presence of co-morbidity, $72.2 \% \mathrm{DM}$ patients with no co-morbidity were non-anemic while $36.3 \%$ of those with DM co-morbidity were anemic. Diabetic patients with DM complications have higher anemia $(47.4 \%)$ than those with no DM complications (24.9\%) (Table 4).

\section{Factors Associated with Anemia}

Bivariate and multivariable logistic regression models were fitted to check the association between anemia and the explanatory variables. In bivariate analysis; age, gender, marital status, Khat chewing, coffee use after meal, presence of co-morbidity, diabetic complications, duration of DM, and nutritional status (BMI) were significantly associated with anemia at $p$-value $<0.25$ and were candidates for multivariable logistic regression.

In multivariable logistic regression, male gender, duration of DM $\geq 5$ years, presence of co-morbidity, and the presence of DM complications were significantly associated with anemia. Male adult DM patients were 2.1 times $(\mathrm{AOR}=2.1,95 \% \mathrm{CI}: 1.2,3.8)$ more likely to have anemia than their female counterparts. DM patients with co-morbidity were 1.9 times $(\mathrm{AOR}=$ $1.9,95 \%$ CI: $1.0,3.7)$ more likely to be anemic than DM patients with no co-morbidity. Those DM patients with a duration of $\mathrm{DM} \geq 5$ years were 1.8 times $(\mathrm{AOR}=$ $1.8,95 \% \mathrm{CI}: 1.1,3.3)$ more likely to be anemic as compared to those with DM duration of $1-5$ years. The odds of anemia were 2.3 times $(\mathrm{AOR}=2.3,95 \%$ CI: 1.3, 4.2) higher among patients with DM complications as compared to their counterparts (Table 4). 
Table 4 Factors Associated with Anemia Among Adult DM Patients Attending a General Hospital in Eastern Ethiopia, 2020 (N=325)

\begin{tabular}{|c|c|c|c|c|c|}
\hline \multirow[t]{2}{*}{ Variables } & \multirow[t]{2}{*}{ Category } & \multicolumn{2}{|l|}{ Anemia } & \multirow[t]{2}{*}{ COR $(95 \% \mathrm{Cl})$} & \multirow[t]{2}{*}{ AOR $(95 \% \mathrm{Cl})$} \\
\hline & & Yes $(n=98)$ & No $(n=227)$ & & \\
\hline Gender & $\begin{array}{l}\text { Male } \\
\text { Female }\end{array}$ & $\begin{array}{l}73(36.0) \\
25(20.5)\end{array}$ & $\begin{array}{l}130(64.0) \\
97(79.5)\end{array}$ & $\begin{array}{l}2.2(1.3,3.7) \\
\text { I }\end{array}$ & $\begin{array}{l}2.1(1.2,3.8)^{*} \\
\text { । }\end{array}$ \\
\hline Age in years & $\begin{array}{l}18-25 \\
26-40 \\
4 I-55 \\
\geq 56\end{array}$ & $\begin{array}{ll}21 & (38.2) \\
30 & (23.3 .) \\
20 & (25.6) \\
27 & (42.9)\end{array}$ & $\begin{array}{l}34(61.8) \\
99(76.7) \\
58(74.4) \\
36(57.1)\end{array}$ & $\begin{array}{l}\text { I } \\
\text { I0.5 }(0.2,0.97) \\
0.6(0.3,1.2) \\
\text { I. } 2(0.6,2.5)\end{array}$ & $\begin{array}{l}\text { I } \\
0.5(0.2, \mathrm{I} . \mathrm{I}) \\
0.5(0.2, \mathrm{I} . \mathrm{I}) \\
0.9(0.4,2.1)\end{array}$ \\
\hline Current Khat chewer & $\begin{array}{l}\text { Yes } \\
\text { No }\end{array}$ & $\begin{array}{l}60(28.7) \\
38(32.8)\end{array}$ & $\begin{array}{l}\text { I49 (7I.3) } \\
78(67.2)\end{array}$ & $\begin{array}{l}0.8(0.5, \mathrm{I} .3) \\
\mathrm{I}\end{array}$ & $\begin{array}{l}0.9(0.5,1.6) \\
1\end{array}$ \\
\hline Coffee use after a meal & $\begin{array}{l}\text { Yes } \\
\text { No }\end{array}$ & $\begin{array}{l}73(32.9) \\
25(24.3)\end{array}$ & $\begin{array}{l}149(67.1) \\
78(75.7)\end{array}$ & $\begin{array}{l}\mathrm{I} .5(0.9,2.6) \\
\mathrm{I}\end{array}$ & $\begin{array}{l}\mathrm{I} .5(0.8,2.8) \\
\mathrm{I}\end{array}$ \\
\hline Duration of DM & $\begin{array}{l}\leq \mathrm{I} \text { year } \\
\mathrm{I}-5 \text { years } \\
\geq 5 \text { years }\end{array}$ & $\begin{array}{l}23(25.3) \\
27(24.3) \\
48(39.0)\end{array}$ & $\begin{array}{l}68(74.7) \\
84(75.7) \\
75(61.0)\end{array}$ & $\begin{array}{l}\text { I.I }(0.6,2.0) \\
\text { I } \\
2.0(I . I, 3.5)\end{array}$ & $\begin{array}{l}\mathrm{I} .4(0.7,2.8) \\
\mathrm{I} \\
\mathrm{I} .8(\mathrm{I} . \mathrm{I}, 3.3)^{*}\end{array}$ \\
\hline Presence of co-morbidity & $\begin{array}{l}\text { Yes } \\
\text { No }\end{array}$ & $\begin{array}{l}33(36.3) \\
65(27.8)\end{array}$ & $\begin{array}{l}58(63.7) \\
169(72.2)\end{array}$ & $\begin{array}{l}\text { I.5 }(0.9,2.5) \\
\text { I }\end{array}$ & $\begin{array}{l}1.9(1.0,3.7)^{*} \\
1\end{array}$ \\
\hline DM complications & $\begin{array}{l}\text { Yes } \\
\text { No }\end{array}$ & $\begin{array}{l}36(47.4) \\
62(24.9)\end{array}$ & $\begin{array}{l}40(52.6) \\
187(75.1)\end{array}$ & $\begin{array}{l}2.7(1.6,4.6) \\
\text { I }\end{array}$ & $\begin{array}{l}2.3(1.3,4.2)^{*} \\
1\end{array}$ \\
\hline Nutritional status (BMI in $\mathrm{kg} / \mathrm{m}^{2}$ ) & $\begin{array}{l}<18.5 \\
18.5-24.9 \\
\geq 25\end{array}$ & $\begin{array}{l}9(27.3) \\
73(36.5) \\
16(17.4)\end{array}$ & $\begin{array}{l}24(72.7) \\
127(63.5) \\
76(82.6)\end{array}$ & $\begin{array}{l}\text { I } \\
\text { I.5 }(0.7,3.5) \\
0.6(0.2,1.4)\end{array}$ & $\begin{array}{l}\text { I } \\
\text { I.4 }(0.6,3.4) \\
0.5(0.2, \mathrm{I} .5)\end{array}$ \\
\hline
\end{tabular}

Note: *Significant at $p$-value $<0.005$.

Abbreviations: AOR, adjusted odds ratio; COR, crude odds ratio.

\section{Discussion}

This study assessed the magnitude of anemia and factors associated with it among DM patients attending their diabetic follow up at Gelemso General Hospital. The magnitude of anemia in the current study was $30.2 \%$. According to public health importance classification by WHO, anemia was a moderate public health problem among adult DM patients in the study setting. Being male in gender, duration of DM, presence of DM complications, and DM co-morbidities were identified as factors associated with anemia.

The magnitude of anemia in this study was comparable to report of study from Dessie Referral Hospital-Ethiopia ${ }^{24}$ but higher than findings of studies from Fenote Selam Hospital-Ethiopia, ${ }^{41}$ a sub-national study in China, ${ }^{42}$ Australia, ${ }^{43}$ and India. ${ }^{44}$ However, it was lower compared to studies conducted in Thailand, ${ }^{45}$ Saudi Arabia, ${ }^{46}$ and Cameroon. ${ }^{47}$ This discrepancy might be due to variations in the age of the study population. For instance, unlike the current study which included adults above 18 years old, a study in Thailand included adults' $\geq 60$ years old, whereas the study from Cameroon included adults' $\geq 50$ years old. The difference could also be due to decreased renal function, inflammation, bone marrow suppression, and malnutrition which is likely as people get aged. ${ }^{17}$

We were surprised that anemia was more common among males than females in our study. This finding is in contrast to other study reports ${ }^{42,48}$ in which the occurrence of anemia was more likely in females than male diabetic patients. The possible reason for this difference might be the higher Khat chewing habits among males in our study, which could lead to the loss of appetite, ${ }^{49}$ and Khat contains Tannin - a substance which reduces the bioavailability of non-heme iron from the diet. ${ }^{50}$ The other possible reason is that the higher coffee and tea consumption among males in the current study inhibits the absorption of iron from the intestine. ${ }^{51-54}$

We found that patients who lived with DM for $\geq 5$ years were more likely to have anemia than those with DM duration of $1-5$ years. This was in line with studies 
conducted in Fenote Selam Hospital-Ethiopia, ${ }^{41}$ Iraq $^{55}$, and UK. ${ }^{17}$ It could be due to the longer exposure to hyperglycemia which leads to increased inflammatory cytokines that have an anti-erythropoietin effect causing a decrease in the number of circulating erythrocytes and consequently causing a reduction of circulating hemoglobin. ${ }^{35}$

In line with the study conducted in China, ${ }^{13}$ anemia was more common among DM patients with complications in this study. Biologically explained, DM complications cause prominent damage to the cells and vascular structure of the kidneys, systemic inflammation, and the induction of inhibitors of erythropoietin release might contribute to anemia in diabetes. ${ }^{56}$ Hypoxia may influence gene expression, metabolism, capillary permeability, and cell survival. ${ }^{57}$ The reduced red blood cells and its antioxidant property associated with anemia could also lead to further complications of the diabetics. ${ }^{58}$

Furthermore, DM patients with co-morbidity were more likely to be anemic than those with no comorbidity. This is comparable with similar previous studies $^{35,59}$ and it could be because of the effect of comorbidity such as hypertension resulting in cardiovascular complications and thereby increase the risk of anemia. $^{60}$

Being one of the very few laboratory-based studies conducted in Ethiopia where chronic disease such as DM is becoming more common constitutes the strength of this study. On the other hand, this study was a single hospitalbased study and might not be representative to all DM patients or those attending follow-ups at other health facilities. The cross-sectional nature of the study design we used did not allow establishing temporal relationship between anemia and the factors. Future studies might need to consider signs and symptoms of anemia, RBC morphology, Serum Iron, Vitamin B12, and Folate levels determination by using study designs such as case control, cohort, or others.

\section{Conclusions}

Anemia was a moderate public health problem among adult DM patients in the study setting. Being male in gender, duration of DM, the presence of DM complications, and co-morbidity were identified as factors associated with anemia. Therefore, routine screening and appropriate management of anemia targeting DM patients with long duration of DM, those with comorbidity, and complications should be devised to improve patients' quality of life. Early diagnosis and regular monitoring of DM could also help to minimize further complications.

\section{Data Sharing Statement}

The data supporting the results reported in the manuscript can be obtained from the corresponding author up on reasonable requests.

\section{Acknowledgments}

We would like to extend our thanks to Gelemso General Hospital head, diabetic clinic staff, study participants, data collectors, and research assistants.

\section{Author Contributions}

All authors made a significant contribution to the work reported, whether that is in the conception, study design, execution, acquisition of data, analysis and interpretation, or in all these areas; took part in drafting, revising or critically reviewing the article; gave final approval of the version to be published; have agreed on the journal to which the article has been submitted; and agree to be accountable for all aspects of the work.

\section{Disclosure}

The authors report no conflicts of interest in this work.

\section{References}

1. WHO. Haemoglobin Concentrations for the Diagnosis of Anaemia and Assessment of Severity. Vitamin and Mineral Nutrition Information System. Geneva, Switzerland. 2011. NMH/NHD/MNM/ 11.1. Available from:: http://www.who.int/entity/vmnis/indicators/hae moglobin. Accessed January 22, 2021.

2. Viteri F. A new concept in the control of iron deficiency: community-based preventive supplementation of at-risk groups by the weekly intake of iron supplements. Biomed Environ Sci. 1998;11(1):46-60.

3. Mehdi U, Toto RD. Anemia, diabetes, and chronic kidney disease. Diabetes Care. 2009;32(7):1320-1326. doi:10.2337/dc08-0779

4. WHO. Worldwide Prevalence of Anaemia 1993-2005. WHO global database on anaemia; 2008.

5. Johnson LJ, Gregory LC, Christenson RH, Harmening DM. Appleton and Lange Series Outline Review Clinical Chemistry. New York: McGraw-Hill; 2001.

6. Gulati M, Agrawal N. Study of prevalence of anaemia in patients with type 2 diabetes mellitus. Sch J App Med Sci. 2016;4(5F):1826-1829.

7. Cawood TJ, Buckley U, Murray A, et al. Prevalence of anaemia in patients with diabetes mellitus. Ir J Med Sci. 2006;175(2):25. doi:10.1007/BF03167944

8. Kuo I-C, Lin -HY-H, Niu S-W, et al. Glycated hemoglobin and outcomes in patients with advanced diabetic chronic kidney disease. Sci Rep. 2016;6:20028. doi:10.1038/srep20028

9. Loutradis C, Skodra A, Georgianos P, et al. Diabetes mellitus increases the prevalence of anemia in patients with chronic kidney disease: a nested case-control study. World J Nephrol. 2016;5(4):358. doi:10.5527/wjn.v5.i4.358 
10. Rajagopal L, Ganesan V, Abdullah S, Arunachalam S, Kathamuthu K, Ramraj B. Exploring the interrelationship between electrolytes, anemia, and glycosylated hemoglobin (Hbalc) levels in type 2 diabetics. Asian J Pharm Clin Res. 2018;11(1):251-256. doi:10.22159/ajpcr.2018.v11i1.22533

11. Angelousi A, Larger E. Anaemia, a common but often unrecognized risk in diabetic patients: a review. Diabetes Metab. 2015;41 (1):18-27. doi:10.1016/j.diabet.2014.06.001

12. CSA-Ethiopia, I.C.F. International. Ethiopia Demographic and Health Survey Key Findings 2016. Central Statistical Agency of Ethiopia and ICF International. Addis Ababa, Ethiopia and Rockville, Maryland, USA;2017.

13. He BB, Xu M, Wei L, et al. Relationship between anemia and chronic complications in chinese patients with type 2 diabetes mellitus. Arch Iran Med. 2015;18(5):277-283.

14. Wright J, Oddy M, Richards T. Presence and characterisation of anaemia in diabetic foot ulceration. Anemia. 2014;2014:1-8. doi:10.1155/2014/104214

15. Thambiah SC, Samsudin IN, George E, et al. Anaemia in type 2 diabetes mellitus (T2DM) patients in Hospital Putrajaya. Malaysian $J$ Med Health Sci. 2015;11(1):49-61.

16. Roman RM, Lobo PI, Taylor RP, et al. Prospective study of the immune effects of normalizing the hemoglobin concentration in hemodialysis patients who receive recombinant human erythropoietin. J Am Soc Nephrol. 2004;15(5):1339-1346. doi:10. 1097/01.ASN.0000125618.27422.C7

17. Trevest K, Treadway H, Hawkins-van DCG, Bailey C, Abdelhafiz AH. Prevalence and determinants of anemia in older people with diabetes attending an outpatient clinic: a cross-sectional audit. Clin Diabetes. 2014;32(4):158. doi:10.2337/diaclin.32.4.158

18. Thomas MC, Cooper ME, Rossing K, Parving HH. Anaemia in diabetes: is there a rationale to TREAT? Diabetologia. 2006;49 (6):1151. doi:10.1007/s00125-006-0215-6

19. New JP, Aung T, Baker PG, et al. The high prevalence of unrecognized anaemia in patients with diabetes and chronic kidney disease: a population-based study. Diabetic Med. 2008;25(5):564-569. doi:10. 1111/j.1464-5491.2008.02424.x

20. Bosman DR, Winkler AS, Marsden JT, Macdougall IC, Watkins PJ. Anemia with erythropoietin deficiency occurs early in diabetic nephropathy. Diabetes Care. 2001;24(3):495-499. doi:10.2337/ diacare.24.3.495

21. McGill JB, Bell DS. Anemia and the role of erythropoietin in diabetes. J Diabetes Complications. 2006;20(4):262-272. doi:10. 1016/j.jdiacomp.2005.08.001

22. Baisakhiya S, Garg P, Singh S. Anemia in patients with type II diabetes mellitus with and without diabetic retinopathy. Int $J$ Med Sci Public Health. 2017;6(2):303-306. doi:10.5455/ijmsph.2017.03 082016604

23. Wikipedia. Gelemso populated places in the Oromia Region 2020 June 11. 2020 [cited on October 20, 2020]. Available from: https://en.wikipedia.org/wiki/Gelemso. Accessed January 22, 2021.

24. Fiseha T, Adamu A, Tesfaye M, Gebreweld A, Hirst JA. Prevalence of anemia in diabetic adult outpatients in Northeast Ethiopia. PLoS One. 2019;14(9):e222111. doi:10.1371/journal.pone.0222111

25. WHO. The WHO Stepwise Approach to Noncommunicable Disease Risk Factor Surveillance. Geneva, Switzerland: WHO; 2017.

26. Aynalem SB, Zeleke AJ. Prevalence of diabetes mellitus and its risk factors among individuals aged 15 years and above in Mizan-Aman Town, Southwest Ethiopia, 2016: a Cross Sectional Study. Int J Endocrinol. 2018;2018:2018. doi:10.1155/2018/9317987

27. Seifu W. Prevalence and risk factors for diabetes mellitus and impaired fasting glucose among adults aged 15-64 years in gilgel gibe field research center, Southwest Ethiopia, 2013: through a who step wise approach. MOJ Public Health. 2015;2(5):00035. doi:10. 15406/mojph.2015.02.00035
28. Roba HS, Beyene AS, Mengesha MM, Ayele BH. Prevalence of hypertension and associated factors in Dire Dawa city, Eastern Ethiopia: a community-based cross-sectional study. Int $J$ Hypertens. 2019;2019:1-9. doi:10.1155/2019/9878437

29. Tesfaye T, Shikur B, Shimels T, Firdu N. Prevalence and factors associated with diabetes mellitus and impaired fasting glucose level among members of federal police commission residing in Addis Ababa, Ethiopia. BMC Endocr Disord. 2016;16(1):68. doi:10.1186/ s12902-016-0150-6

30. Abebe SM, Berhane Y, Worku A, Getachew A, Li Y. Prevalence and associated factors of hypertension: a crossectional community based study in Northwest Ethiopia. PLoS One. 2015;10(4):e0125210. doi:10.1371/journal.pone.0125210

31. Kearney PM, Whelton M, Reynold K, Muntner P, Whelton PK, He J. Global burden of hypertension: analysis of worldwide data. lancet. 2005;365(9455):217-223. doi:10.1016/S0140-6736(05)17741-1

32. Singh S, Shankar R, Singh GP. Prevalence and associated risk factors of hypertension: a Cross-Sectional Study in Urban Varanasi. Int J Hypertens. 2017;2017:2017. doi:10.1155/2017/5491838

33. De Onis M, Habicht JP. Anthropometric reference data for international use: recommendations from a World Health Organization expert committee. Am J Clin Nutr. 1996;64(4):650-658. doi:10.10 93/ajcn/64.4.650

34. WHO. Physical status: the use and interpretation of anthropometry. WHO technical report series. 1995; 854(9).

35. Barbieri J, Fontela PC, Winkelmann ER, et al. Anemia in patients with type 2 diabetes mellitus. Anemia. 2015;2015:2015. doi:10.1155/ 2015/354737

36. Owolabi EO, Ter GD, Adeniyi OV. Central obesity and normal-weight central obesity among adults attending healthcare facilities in Buffalo City metropolitan municipality, South Africa: a cross-sectional study. $J$ Health Popul Nutr. 2017;36(1):54. doi:10.1186/s41043-017-0133-x

37. Adera H, Hailu W, Adane A, Tadesse A. Prevalence of anemia and its associated factors among chronic kidney disease patients at University of Gondar Hospital, Northwest Ethiopia: a Hospital-Based Cross Sectional Study. Int J Nephrol Renovasc Dis. 2019;12:219. doi:10.2147/IJNRD.S216010

38. Chiwanga FS, Njelekela MA, Diamond MB, et al. Urban and rural prevalence of diabetes and pre-diabetes and risk factors associated with diabetes in Tanzania and Uganda. Glob Health Action. 2016;9 (1):31440. doi:10.3402/gha.v9.31440

39. Kassahun T, Eshetie T, Gesesew H. Factors associated with glycemic control among adult patients with type 2 diabetes mellitus: a cross-sectional survey in Ethiopia. BMC Res Notes. 2016;9(1):78. doi:10.1186/s13104-016-1896-7

40. Fana SA, Bunza MDA, Anka SA, Imam AU, Nataala SU. Prevalence and risk factors associated with malaria infection among pregnant women in a semi-urban community of north-western Nigeria. Infect Dis Poverty. 2015;4(1):1-5. doi:10.1186/s40249-015-0054-0

41. Abate A, Birhan W, Alemu A. Association of anemia and renal function test among diabetes mellitus patients attending Fenote Selam Hospital, West Gojam, Northwest Ethiopia: a cross sectional study. BMC Hematol. 2013;13(1):6. doi:10.1186/20521839-13-6

42. Chen CX, Li YC, Chan SL, Chan KH. Anaemia and type 2 diabetes: implications from a retrospectively studied primary care case series. Hong Kong Med J. 2013;19(3):214-221. doi:10.12809/hkmj133814

43. Wee YH, Anpalahan M. The role of older age in normocytic anaemia in type 2 diabetes mellitus. Curr Aging Sci. 2019;12(2):76-83. doi:10.2174/1874609812666190627154316

44. Panda AK, Ambade RA. Prevalence of anemia and its correlation with HBA1c of patients in type-II diabetes mellitus: a pilot study. Natl J Physiol Pharm Pharmacol. 2018;8(10):1409-1413. doi:10. 5455/njppp.2018.8.0621511072018 
45. Sudchada P, Kunmaturos P, Deoisares R. Prevalence of anemia in Thai type 2 diabetic patients with no diagnosis of associated cardiovascular or chronic kidney diseases. Singapore Med J. 2013;28 (2):190-198.

46. Al-Salman M. Anemia in patients with diabetes mellitus: prevalence and progression. Gen Med. 2015;1-4.

47. Feteh VF, Choukem SP, Kengne AP, Nebongo DN, Ngowe-Ngowe M. Anemia in type 2 diabetic patients and correlation with kidney function in a tertiary care sub-Saharan African hospital: a cross-sectional study. BMC Nephrol. 2016;17(1):29. doi:10.1186/ s12882-016-0247-1

48. Idris I, Tohid H, Muhammad NA, et al. Anaemia among primary care patients with type 2 diabetes mellitus (T2DM) and chronic kidney disease (CKD): a multicentred cross-sectional study. BMJ Open. 2018;8(12):12. doi:10.1136/bmjopen-2018-025125

49. Wabe NT, Mohammed MA. What science says about khat (catha edulis forsk)? Overview of chemistry, toxicology and pharmacology. J Exp Integr Med. 2012;2(1):29. doi:10.5455/jeim. 221211.rw.005

50. Al-Motarreb A, Al-Habori M, Broadley KJ. Khat chewing, cardiovascular diseases and other internal medical problems: the current situation and directions for future research. J Ethnopharmacol. 2010;132(3):540-548. doi:10.1016/j.jep.2010.07.001

51. Disler P, Lynch SR, Charlton RW, et al. The effect of tea on iron absorption. Gut. 1975;16(3):193-200. doi:10.1136/gut.16.3. 193

52. Fan FS. Iron deficiency anemia due to excessive green tea drinking. Clin Case Rep. 2016;4(11):1053. doi:10.1002/ccr3.707
53. Kumera G, Haile K, Abebe N, Marie T, Eshete T, Ciccozzi M. Anemia and its association with coffee consumption and hookworm infection among pregnant women attending antenatal care at Debre Markos Referral Hospital, Northwest Ethiopia. PLoS One. 2018;13 (11):e0206880. doi:10.1371/journal.pone.0206880

54. Nelson M, Poulter J. Impact of tea drinking on iron status in the UK: a review. J Hum Nutr Diet. 2004;17(1):43-54. doi:10.1046/j.1365277X.2003.00497.x

55. Abdulqadir AH. Prevalence of anemia of chronic disease and iron deficiency anemia among adult diabetic patients in Erbil City. Zanco $J$ Med Sci. 2014;18(1):674-679. doi:10.15218/zjms.2014.0013

56. Thomas MC, MacIsaac RJ, Tsalamandris C, et al. Anemia in patients with type 1 diabetes. J Clin Endocrinol Metab. 2004;89(9):43 59-4363. doi:10.1210/jc.2004-0678

57. Deicher R, Hörl WH. Anaemia as a risk factor for the progression of chronic kidney disease. Curr Opin Nephrol Hypertens. 2003;12 (2):139-143. doi:10.1097/00041552-200303000-00003

58. Klemm A, Voigt C, Friedrich M, et al. Determination of erythrocyte antioxidant capacity in haemodialysis patients using electron paramagnetic resonance. Nephrol Dial Transplant. 2001;16(11):21 66-2171. doi:10.1093/ndt/16.11.2166

59. Ximenes RMO, Barretto ACP, Silva E. Anemia in heart failure patients: development risk factors. Rev Bras Cardiol. 2014;27(3):189-194.

60. Francisco PMSB, Belon AP, Barros MBDA, et al. Self-reported diabetes in the elderly: prevalence, associated factors, and control practices. Cad Saude Publica. 2010;26(1):175-184. doi:10.1590/ S0102-311X2010000100018

\section{Publish your work in this journal}

Diabetes, Metabolic Syndrome and Obesity: Targets and Therapy is an international, peer-reviewed open-access journal committed to the rapid publication of the latest laboratory and clinical findings in the fields of diabetes, metabolic syndrome and obesity research. Original research, review, case reports, hypothesis formation, expert opinion and commentaries are all considered for publication. The manuscript management system is completely online and includes a very quick and fair peer-review system, which is all easy to use. Visit http://www.dovepress.com/testimonials.php to read real quotes from published authors.

Submit your manuscript here: https://www.dovepress.com/diabetes-metabolic-syndrome-and-obesity-targets-and-therapy-journal 